\title{
Impact of Removal of Copper Leaf (Acalypha fruticosa Forssk.) on Plant Species Diversity and Abundance at Chemeron, Baringo County, Kenya
}

\author{
George Morara Ogendi1,2* (-), Rhoda N. Ondieki², Tabitha W. Njoroge1 \\ ${ }^{1}$ Department of Environmental Science, Egerton University, Njoro, Kenya \\ ${ }^{2}$ Dryland Research Training \& Ecotourism Centre, Chemeron, Egerton University, Njoro, Kenya \\ Email: ^gmorara2009@gmail.com, ^gogendi@egerton.ac.ke
}

How to cite this paper: Ogendi, G.M., Ondieki, R.N. and Njoroge, T.W. (2020) Impact of Removal of Copper Leaf (Acalypha fruticosa Forssk.) on Plant Species Diversity and Abundance at Chemeron, Baringo County, Kenya. Open Journal of Ecology, 10, 341-355.

https://doi.org/10.4236/oje.2020.106021

Received: April 27, 2020

Accepted: May 28, 2020

Published: June 1, 2020

Copyright $\odot 2020$ by author(s) and Scientific Research Publishing Inc. This work is licensed under the Creative Commons Attribution International License (CC BY 4.0).

http://creativecommons.org/licenses/by/4.0/

\begin{abstract}
Invasive plant species may significantly alter plant species community composition and structure thereby negatively impacting on ecosystem services. Their impacts on plant communities may be both direct and indirect. The direct effects may include a reduction in the abundance and diversity of palatable plant species that constitute important forage for livestock, wildlife, and medicines for the local communities. Declines in ecosystem resilience are of the notable indirect effects of invasive species. The aim of this study was to assess the impacts of a plant species, copper leaf (Acalypha fruticosa) on floral diversity and abundance at Chemeron, Baringo County in Kenya. The study was guided by three questions: What is the plant composition in terms of grasses, herbs, shrubs, and trees in the study area? Are there any variations in plant abundance between the two sites (sites with and without Acalypha fruticosa)? Are there variations in plant species diversity between the two study sites? Two sites (one with $A$. fruticosa and another two without this invasive species) were selected within the Chemeron Research Centre. Two belt transects measuring $100 \mathrm{~m} \times 20 \mathrm{~m}$ on each site were laid parallel to each other. Plant samples were collected from five $1 \mathrm{~m} \times 1 \mathrm{~m}$ quadrats that were laid at intervals of $20 \mathrm{~m}$. The plant species or specimens were identified to the species level using available taxonomic keys. Various indices including Shannon-Wiener $\left(H^{p}\right)$, Evenness Index, Richness Index and Simpson's Index of Diversity Index (SDI) were calculated. All the diversity, richness and evenness indices were considerably higher in the site without $A$. fruticosa compared to that where this invasive species was present. Higher $H^{P}$ (3.14 to 3.21) and SDI (0.93 to 0.94$)$ values were noted in sites without the invasive species compared to $H^{p}$ (2.11 to 2.20$)$ and SDI (0.77 to 0.85$)$ in sites with $A$. fruticosa
\end{abstract}


present. Out of the 47 plant species identified, 39 and 20 of them occurred in the site without and with $A$. fruticosa, respectively. Further, there were more grasses (Aristida keniensis, Cynodon dactylon, Brachiaria lucrantha, Eragrostis racemosa, and Enteropogon macrostachyus) in the site without $A$. fruticosa compared to that with the invasive plant. The plants were also more evenly distributed in the site without $A$. fruticosa compared to that where the invasive plant was present. We conclude that $A$. fruticosa has a significant effect on plant species abundance and diversity as well as distribution. Its removal created a favourable environment for the growth of a variety of grasses. We therefore recommend to the agro-pastoralists and rangeland managers that $A$. fruticosa be mechanically removed by uprooting from grazing lands so as to increase forage availability and quality in the rangelands of South-Baringo.

\section{Keywords}

Baringo, Copper Leaf, Diversity Indices, Invasive Species Plant Diversity

\section{Introduction}

Globally, rangelands have been identified as an ecological reservoir of genetic diversity [1] [2], and provide forage and habitats for millions of animals [3]. They have also been recognized for their role in carbon sequestration, prevention of soil erosion, promotion of soil development and nutrient cycling [4] [5]. Rangelands support over 40 million people that mostly practice agro-pastoralism and/or nomadism. Many rural and peri-urban communities derive their food, fuel, and building materials from rangelands. They provide habitats for wildlife that forms the economic base for many Sub-Saharan countries through tourism and trophy hunting as well as many nature-based tourism enterprises such as nature trails, cultural tourism, wildlife photography, bird watching and ethnobotany.

Unfortunately, rangelands are threatened by anthropogenic activities including deforestation, overgrazing, charcoal burning, human settlements and introduction of species some of which end up being invasive. The invasive plant species lead to declines in the ability of rangelands to provide goods, ecosystem services and functions. It is against this background that in the past few decades, considerable attention has been paid to the negative effects of invasive species on resident communities and functioning of invaded ecosystems [5] [6]. Some of these invasive species are woody plants, and the mechanisms to deal with bush encroachment in the rangelands have remained relatively unclear. Further, biological invasions have led to significant effects on biodiversity all over the world. Among the large scale effects of plant invasions include the homogenisation of floras, when originally a particular area had a diverse range of floras [7]. This suppression of the native species is because of the dominance of the invasive species.

Besides their effects on biodiversity, invasive species cause disruptions on 
ecosystem services and functions. Invasive species may alter community structure through exploitation competition, mainly from indirect interactions like resource use, and interference competition through direct interactions like allellopathy [8]. This may eventually result in extinction of plant species, whereby the abundance of some native species with certain key traits that influence ecosystem processes are greatly reduced [9]. Changes in the species and community structure have both direct and indirect effects on ecosystem services. Direct effects may include reduction in the abundance of valuable plant species which may have been used as food, forage for livestock or even medicine by the local community. Indirect effects may include a decrease in the ecosystem resistance and resilience to change, mainly due to the hypothesized linkage between stability and changes in the biodiversity [10].

Invasive species can also alter physical habitats and disturbance regimes of ecosystems. Disturbance regimes like fires are beneficial in the rangelands and to the climate in general in that they may be involved in the stabilisation of atmospheric composition (e.g. through increased nitrogen volatilization), forage quality for the cattle and other animals. Occurrence of fires may be reduced by invasive trees in the grasslands or enhanced by the invasion of grasses in the shrublands. Comparison between the invaded and the uninvaded sites helps in the identification of potential effects of an invasive species, and also provides valuable information for landscape management and nature conservation [11] [12]. The aim of this study was to understand the effects of copper leaf (Acalypha fruticosa Forssk) on species diversity and abundance at Chemeron (an Arid and Semi-Arid Land) in South-Baringo, Kenya. The study was guided by three questions: What is the plant composition in terms of grasses, herbs, shrubs, and trees in the study area? Are there any variations in plant abundance between the two sites (sites with and without Acalypha fruticosa)? Are there variations in plant species diversity between the two study sites? In this study, we hypothesized that the presence of copper leaf (Acalypha fruticosa) will lead to a decline in native species thus reduce abundance and diversity of plants. Thus its removal should result in an increase in the diversity, species richness and relative abundance of plants in the study site.

\section{Materials and Methods}

\subsection{Study Area}

The study site is located within the Chemeron Dryland Research Training and Ecotourism Centre (Figure 1), which is approximately $120 \mathrm{~km}$ northwest of Nakuru town. It is approximately $11 \mathrm{~km}$ from Marigat town, and $2 \mathrm{~km}$ off the Marigat-Kabarnet road, in Baringo County. It is located within Agro-Ecological Zone $\mathrm{V}$ and receives an annual rainfall of about $635 \mathrm{~mm}$ annually. The rainfall is less than $30 \%$ reliable with high variability. The long rains fall in the months of April to July whereas the short rains fall between end of September and early November. The driest months occur between January to March. The altitude at 


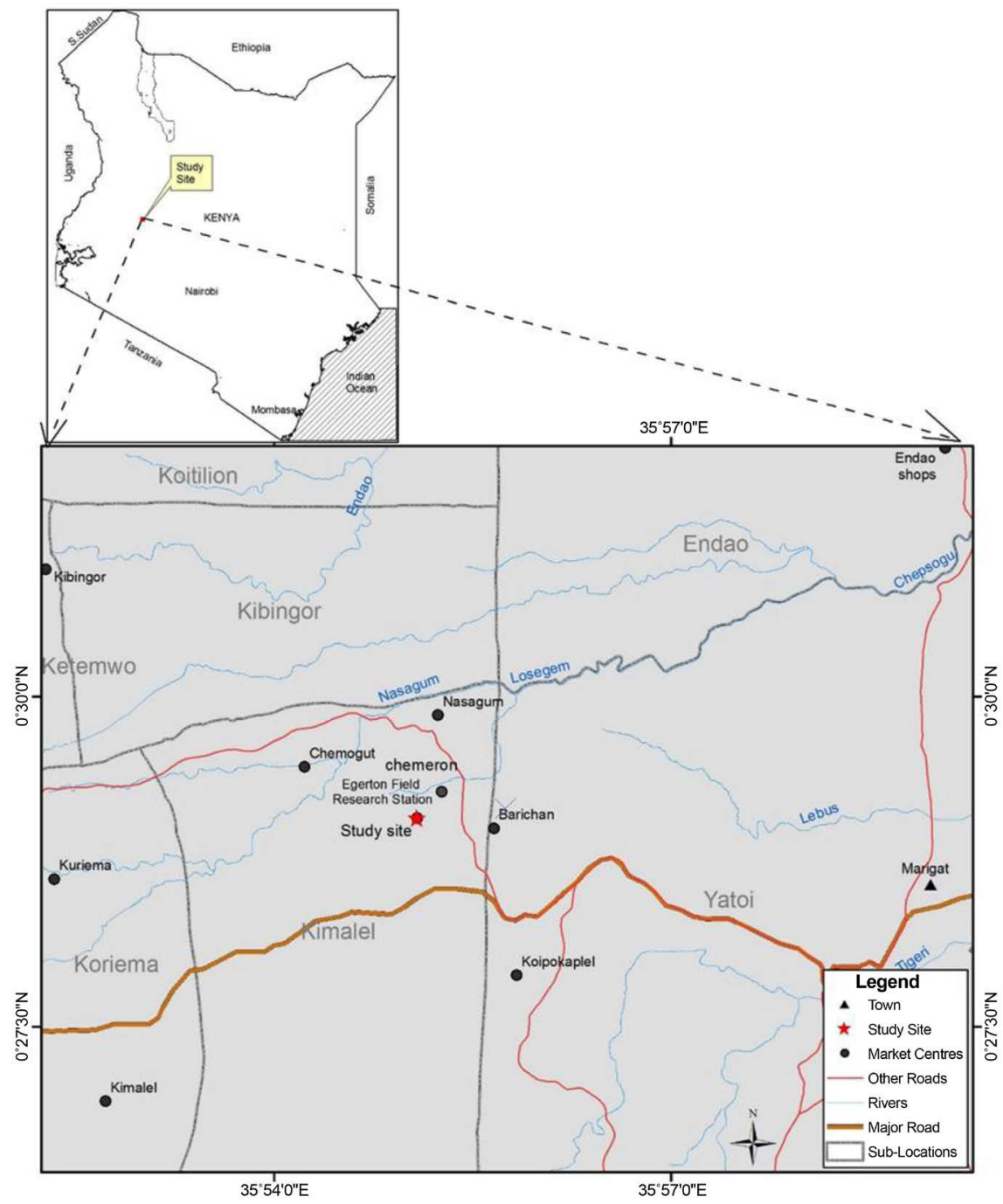

Figure 1. Map of Baringo county (map of Kenya inset) showing the study site.

the study area is approximately $1200 \mathrm{~m}$ above sea level. The temperature ranges from $25^{\circ} \mathrm{C}$ to $38^{\circ} \mathrm{C}$. The soils are reddish brown, sandy loam with many rocky outcrops that makes it unsuitable for the growth of many of the commercial food crops in Kenya (e.g. Maize, wheat, tea, coffee, etc.). The ground has a gentle slope and drains into the Chemeron River, a seasonal river that drains into Lake Baringo via the Perkerra River.

The vegetation of the area is mainly dominated by different species of acacia, among them Acacia mellifera, Acacia tortilis, Acacia reficiens, Acacia brevispica and Acacia senegal. Other trees and shrubs in the study area include: Boscia anguistifolia, Balanites aegyptiaca, Grewia bicolor, Terminalia brownii, Maerua angolensis, Acalypha fruticosa and Berchemia discolour. The main grass species in the area include Aristida keniensis, Chloris roxburghiana and Eragrostis superba. The soils are not well developed and thus the prevalence of agro pastoralism characterized by beekeeping and livestock production involving goats and cattle as the preferred animal species. The growing of commercial crops is inhi- 
bited by the dry, rocky and shallow sandy soil conditions. The area is suitable for the cultivation of drought tolerant crops including finger and pearl millet, pigeon peas, vegetables and fruit crops such as mangoes, pawpaws and lemons.

Of the 1100 acres of land belonging to the Chemeron DRTEC, approximately 60 acres of it has been fenced off and livestock excluded from the area, whereas the rest constitutes the grazing fields for goats and cattle. Acalypha fruticosa was removed by uprooting from the enclosed area in 2013/2014 and natural restoration took place over the years.

\subsection{Research Design, Sampling, Sample Processing and Data Analysis}

To achieve the objectives of this study, two sites with contrasting features (enclosed and open sites) were selected for this study. First, an area devoid of interference from livestock through grazing was selected. This site was within the 60-acre fenced area at the Chemeron DRTEC while the other site was in the open grazing fields. The transects within the enclosed area are herein labelled as $A F A-A$ \& $A F A-B$ corresponding with Transect $\mathrm{A}$ and Transect $\mathrm{B}$ without Acalypha fruticosa, respectively. The transects within the open grazing area are herein labelled as $A F P-A \& A F P-B$ corresponding with Transect A and Transect B with Acalypha fruticosa, respectively. The main plant species in the area included Indigofera arrecta, Silene spp., Microchloa kunthi, Aristida keniensis, etc. The enclosed area was kept $A$. fruticosa-free through regular uprooting of the invasive shrub. The Transect and Quadrat Technique (TAQ) was used in the study of plant composition, relative abundance and diversity. Four transects (two within an enclosed area (Acalypha fruticosa absent, AFA), and two in an adjacent open area (Acalypha fruticosa present, AFP) measuring $100 \mathrm{~m}$ by $20 \mathrm{~m}$ were selected for this study. Samples of different plant life forms (herbs, grasses) were collected from quadrats measuring $1 \mathrm{~m} \times 1 \mathrm{~m}$ laid systematically at intervals of $20 \mathrm{~m}$ in both the enclosed and open areas (Figure 2). Shrubs and trees were sampled using $5 \mathrm{~m} \times 5 \mathrm{~m}$ quadrats. Data was analyzed by use of Species Richness Index (D) [13] and diversity assessed using Shannon-Weiner diversity index $(H)[14]$.

$$
H=\sum(p l)|\ln p l|
$$

where $p i$ is the proportion of the total number of individuals in the sample that are in species $i$.

Species richness was calculated using the equation below:

$$
\text { Maximum number of species, } H_{\max }=\ln (S)
$$

$S$ is the total number of species in the samples

$$
D=S / \sqrt{N}
$$

where $S$ is the number of different species in the sample.

$N$ is the total number of individuals in the sample

$$
\text { Evenness was calculated as } H / H_{\max }
$$




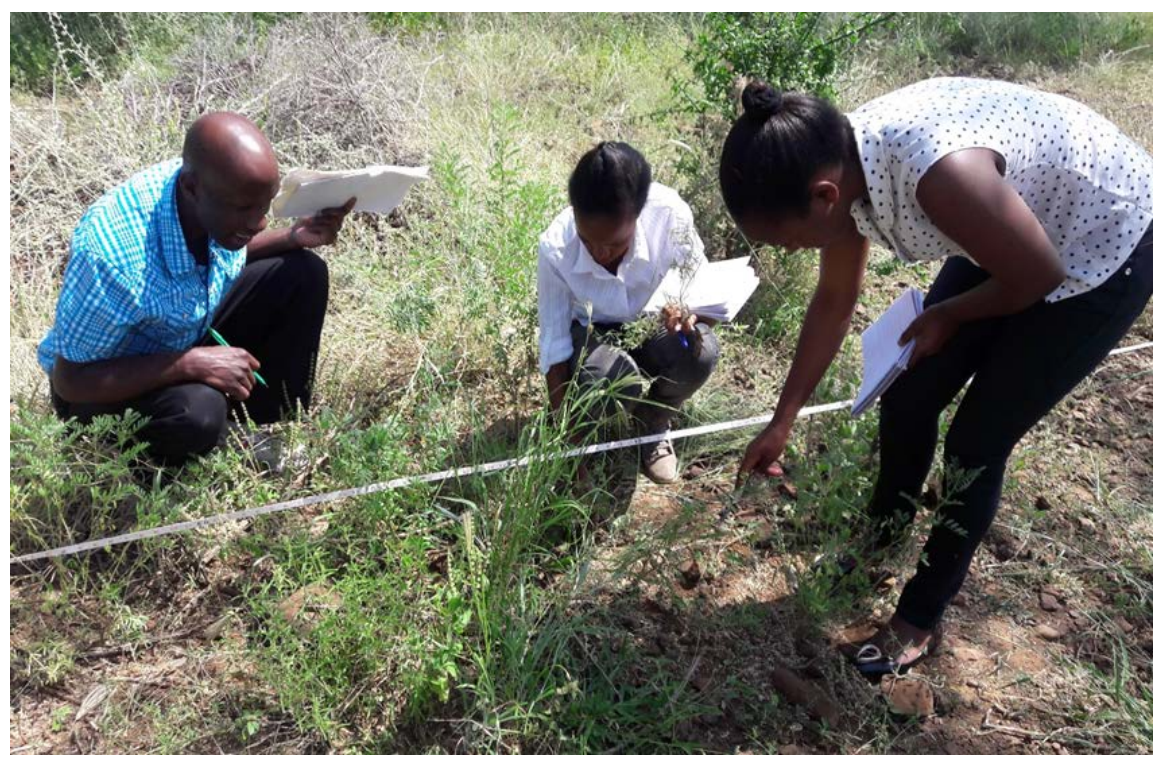

Figure 2. Researchers conducting a plant species survey in one of the transects without Acalypha fruticosa at Chemeron DRTEC.

References to the equations and protocols used in this study are as described in Shannon \& Weiner [14], Magurran [13], and Ibrahim [1].

In each plot, all species of plants were recorded and documented in terms of family, form, species, and uses. Determination of plant species abundance and diversity was done as per protocols describe in Ibrahim [1] and Magurran [13]. The effects of the invasive species (Acalypha fruticosa) were determined through comparison of differences in species richness, $S$, Shannon-Wiener index and evenness in the two study sites. Species distribution in the study site was determined through observation of how different plant species were evenly spread in a transect. Species diversity takes into account both the numbers of species present and the dominance or evenness of species in relation to one another. Whereas several plant diversity indices were calculated, the Shannon-Wiener diversity index was the best suited to measure the species diversity in the study sites as it is fairly sensitive to site differences. The invasive species was excluded from the calculation of community characteristics.

\section{Results}

\subsection{Species Composition and Diversity}

The plant survey yielded a total of 47 species of which 37 of them occurred in the sites where Acalypha fruticosa had been removed (AFA). Only 20 plant species were collected from the transects in the site with present Acalypha fruticosa (AFP). Thus variations in species composition between the two study sites were noted (Figure 3). The plants constituted annuals (e.g. Aristida keniensis, Tribulus cestoides, Oxygonium sinuatum) and perennials (e.g. Aeva persica, Indigofera arrecta, Acacia species, and Acalypha fruticosa). Our results indicated that the removal of Acalypha fruticosa (copper leaf) significantly increased species 


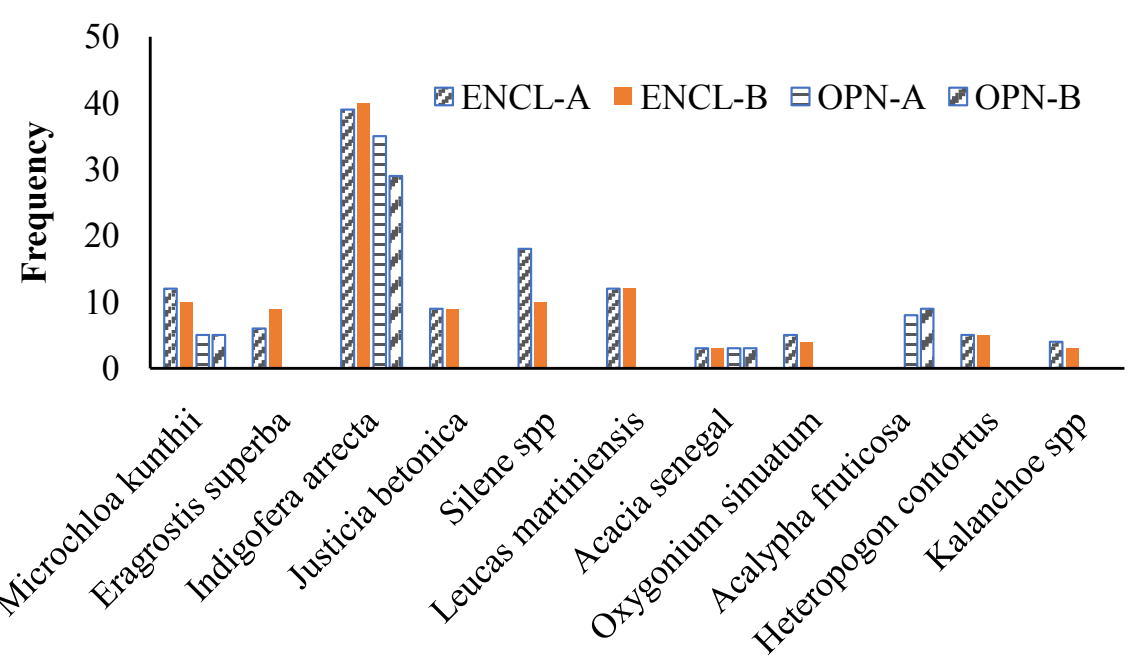

Plant Species

(a)
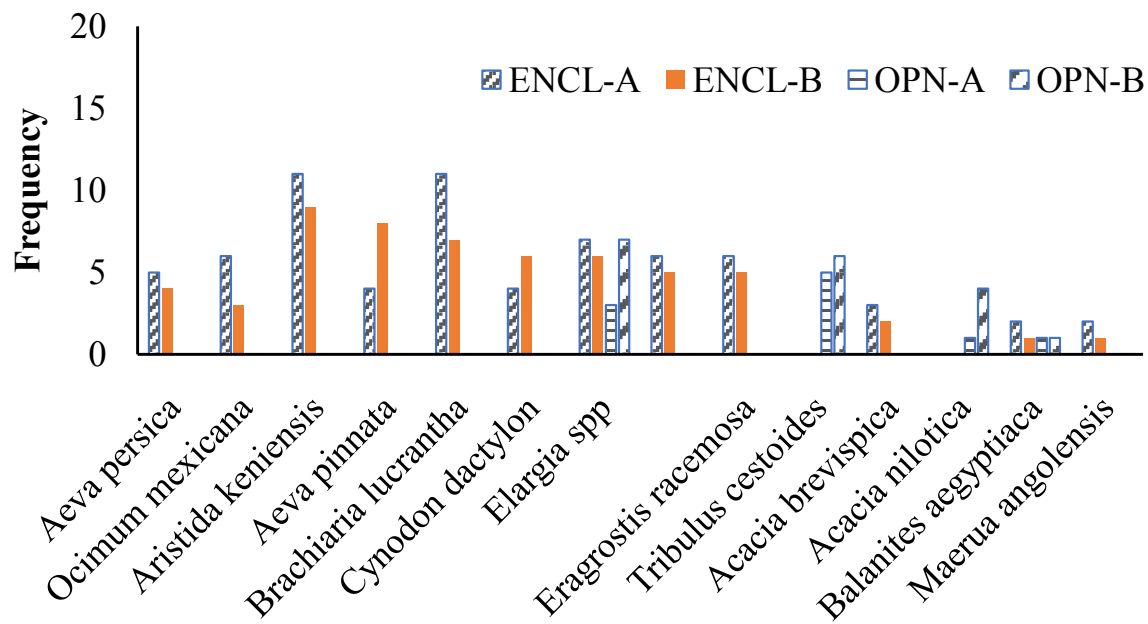

Plant Species

(b)
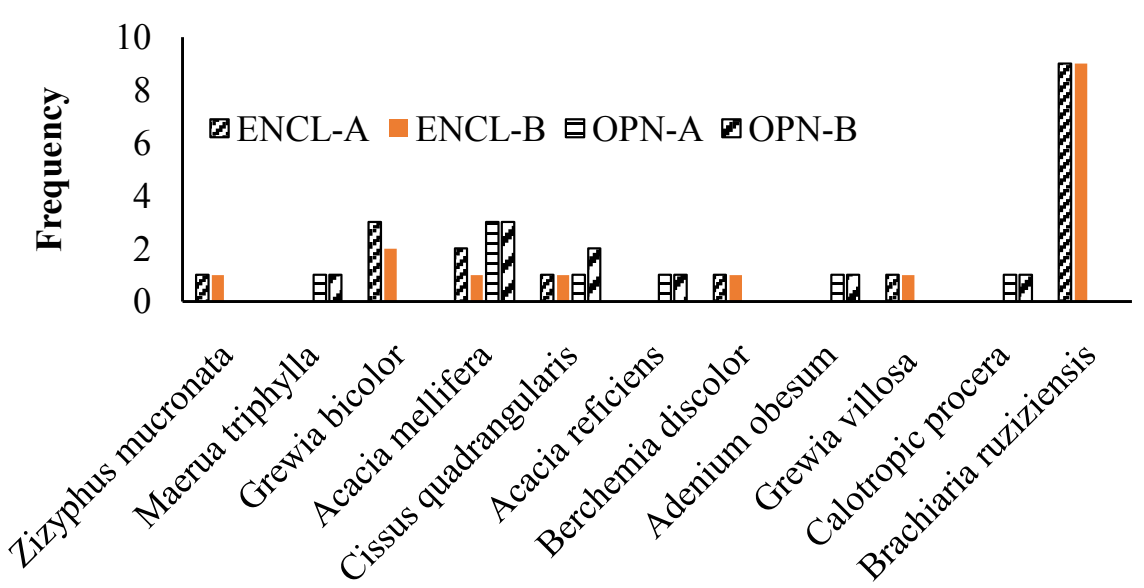

Plant Species

(c) 


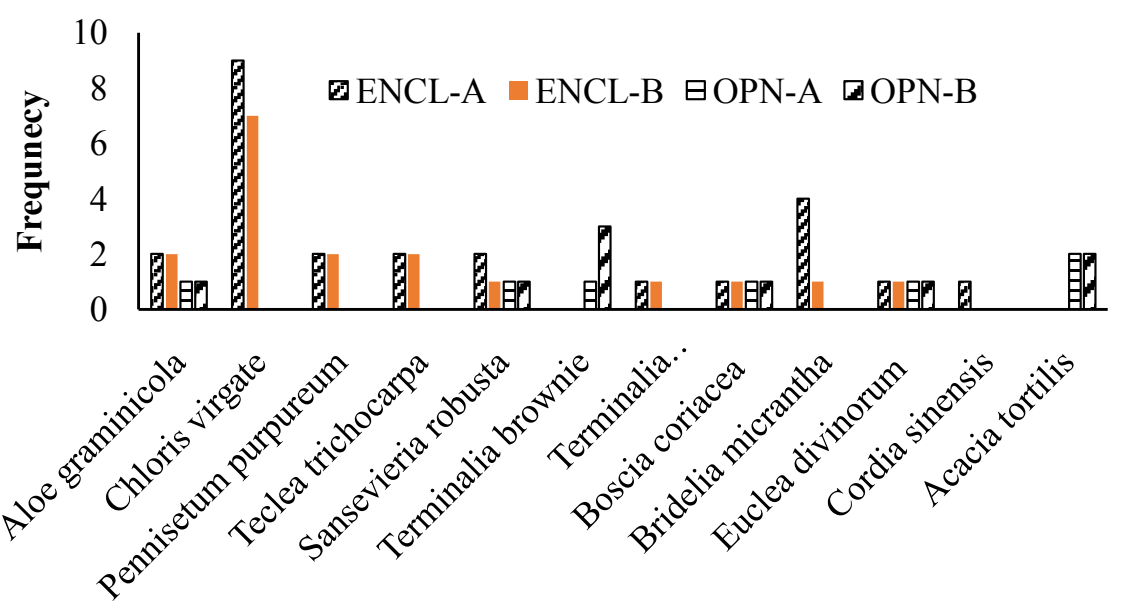

Plant Species

(d)

Figure 3. Frequency distribution of various plant species in transects at two sites (with and without Acalypha fruticosa) at Chemeron DRTEC in Baringo County.

abundance and diversity (Figure 5; Table 1). The dominant plant species in the AFA sites included: Indigofera arrecta, Silene species, Microchloa kunthi, Aloe graminicola, and Ocimum Mexicana (Figure 3). In the AFP sites, the dominant species were Indigofera arrecta, Acalypha fruticosa, Microchloa kunthii, and Acacia senegal (Figure 3). Approximately $47 \%$ of the plants in the survey were shrubs whereas the lowest were trees at $11 \%$ (Figure 4 ). The dominant plant species among the shrubs was Indigofera arrecta. More than $80 \%$ of the grasses enumerated during the survey occurred in the site where Acalypha fruticosa had been removed.

Various indices including Shannon-Wiener $\left(H^{p}\right)$, Evenness Index, Richness Index and Simpson's Index of Diversity Index (SDI) were calculated. All the indices were considerably higher in the site without $A$. fruticosa compared to that where this invasive species was present (Figure 5). Significant differences were also observed in the Shannon-Wiener Index $(t=12.75 ; \mathrm{p}=0.025)$, Evenness In$\operatorname{dex}(t=5.88 ; p=0.04)$ and species richness $(t=26.87 ; p=0.001)$. However, no significant differences were observed in the Simpson's Diversity Index $(t=3.35$; $\mathrm{p}=0.18)$.

\subsection{Discussion}

Diversity in range plant community has several benefits, among them being that a mixture of plants provide forage for a variety of insects and vertebrate species. This will therefore enhance biodiversity in the rangeland. Having a mixture of plants will mean that some of the plants may survive drought, insect plagues and disease outbreaks in the event of occurrence. Therefore, the rangeland will have some soil protection as well as fodder in such periods. A mixture of plants in the rangeland is also beneficial in that some of the plants may be nitrogen fixers hence improving soil conditions, some may be deep rooted thereby bringing nutrients 
Table 1. A summary of the botany and uses of plants documented during a survey at Chemeron DRTEC, Baringo County, Kenya.

\begin{tabular}{|c|c|c|c|c|}
\hline $\begin{array}{l}\text { Botanical Name of } \\
\text { Plant Species }\end{array}$ & Common Name & Family Name & Life form & Uses of plant \\
\hline Microchloa kunthii & Kunth's small grass & Poaceae & Grass & Protects the soil from erosion; also used as fodder. \\
\hline Eragrostis superba & Saw-tooth love grass & Poaceae & Grass & Livestock fodder. \\
\hline Indigofera arrecta & Barkelat (Tugen) & Fabacea & Shrub & Arthritis; fodder for livestock. \\
\hline Justicia betonica & Paper plume & Acanthaceae & Shrub & $\begin{array}{l}\text { It is used as remedy for fevers, stomach pain, diarrhoea, } \\
\text { inflammation and swelling. It has external wound healing and } \\
\text { ulcer healing properties. }\end{array}$ \\
\hline Silene spp & & Caryophyllaceae & Herb & Roots are used to prepare concoctions for various rituals. \\
\hline Leucas martinicensis & Whitewort & Lamiaceae & Herb & $\begin{array}{l}\text { Used as mosquito repellent; manages infectious diseases, } \\
\text { inflammatory conditions, rashes, diarrhoea, convulsions and } \\
\text { epilepsy. }\end{array}$ \\
\hline Acacia senegal & $\begin{array}{l}\text { Gum Senegal tree, } \\
\text { Chemanga (Tugen) }\end{array}$ & $\begin{array}{c}\text { Fabaceae } \\
\text { (Mimosaceae) }\end{array}$ & Shrub & $\begin{array}{l}\text { Its gum is used as a food additive. Seeds used as food by } \\
\text { humans. It is nitrogen fixing and has medicinal value as it } \\
\text { treats bronchitis, diarrhea, gonorrhea and leprosy. }\end{array}$ \\
\hline Oxygonum sinuatum & Wavy-leaf oxygonum & & Herb & $\begin{array}{l}\text { Used as a vegetable, the leaves are applied on boils, and stems } \\
\text { are chewed to treat tonsillitis. }\end{array}$ \\
\hline Acalypha fruticosa & $\begin{array}{l}\text { Copper leaf, } \\
\text { Lokuru (Tugen) }\end{array}$ & Euphorbiaceae & Shrub & $\begin{array}{l}\text { Eaten as a vegetable. Acts as an important browse plant for } \\
\text { sheep/ goats. The stem can be used to make arrow shafts and } \\
\text { the leaves are dried to make tea. }\end{array}$ \\
\hline Heteropogon contortus & Black spear grass & & Grass & $\begin{array}{l}\text { Used for thatching houses, making mats, and fodder for } \\
\text { livestock. }\end{array}$ \\
\hline Kalanchoe densiflora & & Crassulaceae & Herb & $\begin{array}{l}\text { Treats infections, rheumatism and inflammation. Its } \\
\text { extracts have immunosuppressive effects. }\end{array}$ \\
\hline Aeva persica & Desert cotton & Amaranthaceae & Herb & Used as a purgative, antidiarrheal, and anthelmintic. \\
\hline Ocimum gratissimum & Ram Tulsi & & Herb & $\begin{array}{l}\text { Treats colds, blocked nose, stamachache relief, sore eyes, as a } \\
\text { disinfectant and insecticide. }\end{array}$ \\
\hline Aristida kenyensis & Needle grass & Poaceae & Grass & Used as cover grass, thatching houses, and livestock fodder. \\
\hline Aeva pinnata & & & Herb & \\
\hline Brachiaria brizantha & Bread grass & Poaceae & Grass & $\begin{array}{l}\text { Used as pasture for livestock. It is also grown as ornamental } \\
\text { hedges and for erosion control. }\end{array}$ \\
\hline Cynodon dactylon & $\begin{array}{l}\text { Couch grass, bermuda } \\
\text { grass, quick grass and } \\
\text { twitch grass }\end{array}$ & Poaceae & Grass & $\begin{array}{l}\text { Controls erosion, farm pastures, used for indigestion and } \\
\text { treatment of wounds. }\end{array}$ \\
\hline Erlangea marginata & & Asteracea & Shrub & Skin, Stomach and oral cavity infection. \\
\hline $\begin{array}{l}\text { Enteropogon } \\
\text { macrostachyus }\end{array}$ & Needle grass & Poaceae & Grass & Used as livestock fodder. \\
\hline Eragrostis racemosa & Narrow heart love grass, & Poaceae & Grass & Used as a groundcover, forage for livestock; and as bee forage. \\
\hline Tribulus cistoides & $\begin{array}{l}\text { Jamaican feverplant, } \\
\text { puncture vine }\end{array}$ & Zygophyllales & Herb & $\begin{array}{l}\text { Used as a ground cover, treats headache, nervous disorders } \\
\text { and constipation. }\end{array}$ \\
\hline Acacia brevispica & $\begin{array}{c}\text { Kornes (Tugen), } \\
\text { Wait-a-bit thorn (Eng) }\end{array}$ & $\begin{array}{c}\text { Fabaceae } \\
\text { (Mimosaceae) }\end{array}$ & Shrub & $\begin{array}{l}\text { Fibre from young bark makes strong ropes. Used as cattle feed } \\
\text { and is browsed to a considerable extent by goats. }\end{array}$ \\
\hline Acacia nilotica & $\begin{array}{l}\text { Nile thorn, } \\
\text { Chebiywo (Tugen) }\end{array}$ & $\begin{array}{c}\text { Fabaceae } \\
\text { (Mimosaceae) }\end{array}$ & Tree & $\begin{array}{l}\text { Twig used as a toothbrush. Used as animal fodder and as } \\
\text { forage. Good fencing material and for hedging due to its } \\
\text { thorns. }\end{array}$ \\
\hline
\end{tabular}




\section{Continued}

\begin{tabular}{|c|c|c|c|c|}
\hline Balanites aegyptiaca & $\begin{array}{l}\text { Desert date, Ngoswet } \\
\text { (Tugen) }\end{array}$ & Balanitaceae & Tree & $\begin{array}{l}\text { Leaves eaten raw or cooked } \\
\text { Used as animal fodder. Has medicinal value where the oil is } \\
\text { consumed for headaches or used to improve lactation. }\end{array}$ \\
\hline Maerua angolensis & Bead bean & Capparaceae & Shrub & $\begin{array}{l}\text { The leaves are used during famine periods as a food } \\
\text { supplement. Plant treats anorexia and the bark extracts used } \\
\text { to heal wounds. }\end{array}$ \\
\hline Zizyphus mucronata & $\begin{array}{l}\text { Buffalo thorn, } \\
\text { Noiwet (Tugen) }\end{array}$ & Rhamnaceae & Shrub & $\begin{array}{l}\text { Acts as a natural fence. Provides shade from lightning, used as } \\
\text { a painkiller and the leaves are edible as they can be cooked } \\
\text { into tasty spinach. }\end{array}$ \\
\hline Maerua triphylla & Small bead bean & Capparaceae & Shrub & $\begin{array}{l}\text { Produces charcoal and cures dizziness, headache and venereal } \\
\text { diseases. Fresh roots are chewed to treat snake bites and the } \\
\text { leaves are cooked and eaten during food shortage. Maasai } \\
\text { community consider it good fodder for donkeys and goats. }\end{array}$ \\
\hline Grewia bicolor & $\begin{array}{l}\text { White raisin } \\
\text { Sitewo (Tugen) }\end{array}$ & Tiliaceae & Shrub & $\begin{array}{l}\text { Fruits are edible and are of local commercial importance. Has } \\
\text { medicinal value as it cures stomach upsets, skin and intestinal } \\
\text { infections. }\end{array}$ \\
\hline Acacia mellifera & $\begin{array}{l}\text { Blackthorn, Honey acacia } \\
\text { Ng'oror (Tugen) }\end{array}$ & $\begin{array}{c}\text { Fabaceae } \\
\text { (Mimosaceae) }\end{array}$ & Shrub & $\begin{array}{l}\text { Good for fencing, livestock feed and building material for } \\
\text { huts. Flowers are a source of nectar for honey producing bees. } \\
\text { Wood is highly prized for fuel and charcoal making. }\end{array}$ \\
\hline Cissus quadrangularis & $\begin{array}{l}\text { Devils backbone, } \\
\text { Cherorowo (Tugen) }\end{array}$ & Vitaceae & Shrub & $\begin{array}{l}\text { Tortoise food. Acts as traditional medicine as it treats broken } \\
\text { bones, injured ligaments and tendons as well as in treating } \\
\text { stomach upsets. }\end{array}$ \\
\hline Acacia reficiens & $\begin{array}{l}\text { Red bark acacia, red } \\
\text { thorn, False umbrella } \\
\text { tree, Barsule (Tugen) }\end{array}$ & $\begin{array}{c}\text { Fabaceae } \\
\text { (Mimosaceae) }\end{array}$ & Shrub & $\begin{array}{l}\text { Wood used to build temporary houses, used as firewood, } \\
\text { charcoal and the straight stems as poles. Branches are used for } \\
\text { fencing and the thorns for ear piercing. }\end{array}$ \\
\hline Berchemia discolor & $\begin{array}{l}\text { Wild almond (En) } \\
\text { Muchukwa (Tugen) }\end{array}$ & Rhamnaceae & Shrub & $\begin{array}{l}\text { Used as fodder. Fruits and gum are edible. The fruits eaten } \\
\text { and boiled with sorghum. The leaves are used to make tea and } \\
\text { the wood is excellent for making furniture and produces dye. }\end{array}$ \\
\hline Adenium obesum & $\begin{array}{l}\text { Desert rose, Impala lily, } \\
\text { Mwadiga (Swahili) }\end{array}$ & Apocynaceae & Shrub & $\begin{array}{l}\text { Used as a house plant. The toxic sap from its roots and stem is } \\
\text { used as arrow poison for hunting and as fish toxin. }\end{array}$ \\
\hline Grewia villosa & $\begin{array}{l}\text { Grey leaved saucer berry, } \\
\text { Grey leaved cordial, } \\
\text { Salabani (Tugen) }\end{array}$ & Boraginaceae & Shrub & $\begin{array}{l}\text { Has food as well as non-food uses. Its roots are used to treat } \\
\text { body pain, wounds, syphilis and small pox. Has good quality } \\
\text { fibre and the small stems are used as walking sticks. }\end{array}$ \\
\hline Calotropis procera & $\begin{array}{l}\text { Rubber bush, Rubber } \\
\text { tree, } \\
\text { Labosake (Tugen) }\end{array}$ & Asclepiadaceae & Shrub & $\begin{array}{l}\text { Eaten as fruit. Has cultural significance and the fibrous } \\
\text { content from the seeds used in filling pillows. Acts as a } \\
\text { traditional medicine and used in treating cases of cutaneous } \\
\text { diseases, intestinal worms, coughs, asthma and paralysis. }\end{array}$ \\
\hline Brachiaria ruziziensis & Congo Signal grass & Poaceae & Grass & $\begin{array}{l}\text { Forage crop, acts as a permanent/semi-permanent grass for } \\
\text { pasture. It's a very palatable crop having a digestibility of } 55 \% \\
-75 \% \text {. }\end{array}$ \\
\hline Aloe graminicola & $\begin{array}{l}\text { Tengeretwa (Tugen) } \\
\text { Mlalangao (Swahili) }\end{array}$ & Aloaceae & Shrub & $\begin{array}{l}\text { Leaves used locally for treating colds, malaria/Hepatitis. Roots } \\
\text { are taken to treat anaemia and used to make dye. It's also } \\
\text { grown for aesthetic value. }\end{array}$ \\
\hline Chloris virgate & $\begin{array}{l}\text { Feather finger grass, } \\
\text { Feather windmill grass, } \\
\text { Old lands grass }\end{array}$ & Poaceae & Grass & $\begin{array}{l}\text { Has medicinal value as it treats arthritis, rheumatism and } \\
\text { nasopharyngeal infections. }\end{array}$ \\
\hline Pennisetum purpureum & $\begin{array}{l}\text { Nappier grass, Elephant } \\
\text { grass }\end{array}$ & Poaceae & Grass & $\begin{array}{l}\text { Fodder for livestock, Prevents soil erosion. Improves soil } \\
\text { fertility and used as a source of fuel. }\end{array}$ \\
\hline
\end{tabular}




\section{Continued}

\begin{tabular}{|c|c|c|c|c|}
\hline Teclea trichocarpa & $\begin{array}{l}\text { Chepkoriande (Tugen), } \\
\text { Furry fruited Teclea } \\
\text { (Eng) }\end{array}$ & Rutaceae & Shrub & $\begin{array}{l}\text { Treats malaria. Used as an anthelmintic and a vapour inhalant } \\
\text { for treatment of fever. }\end{array}$ \\
\hline Sansevieria robusta & $\begin{array}{l}\text { Snake plant, } \\
\text { Mother in laws tongue, } \\
\text { Kelembel (Tugen) }\end{array}$ & Dracaenaceae & shrub & A small ornamental plant that is good for decorative purposes. \\
\hline Terminalia brownii & $\begin{array}{l}\text { Koloswet (Tugen), } \\
\text { Mukhonje (Luyha), } \\
\text { Muuku (Kamba), } \\
\text { Murukuruku (Meru) }\end{array}$ & Combretaceae & Tree & $\begin{array}{l}\text { The juice from chewing its phloem fibre is swallowed to treat } \\
\text { jaundice and yellow fever in children. Boiling its leaves } \\
\text { induces abortion and the roots are boiled to treat allergies. }\end{array}$ \\
\hline $\begin{array}{c}\text { Terminalia } \\
\text { kilimandscharica }\end{array}$ & Chepchuboiwo (Tugen) & Combretaceae & Tree & Used as forage in the dry season. \\
\hline Boscia coriacea & Sirkwa (Tugen) & Capparidaceae & Tree & $\begin{array}{l}\text { Firewood. Furniture. Bark and roots used as medicine. Used } \\
\text { to makes utensils such as wooden spoons. Shade. } \\
\text { Toothbrushes. Veterinary medicine. }\end{array}$ \\
\hline Bridelia micrantha & Ngorouet (Nandi) & Euphorbiaceae & Shrub & $\begin{array}{l}\text { Used for firewood. Used for charcoal. Used to make poles. } \\
\text { Used to make construction material for granaries. Its bark, } \\
\text { roots and leaf sap are used as medicine. Used for river bank } \\
\text { stabilization. Edible fruit. }\end{array}$ \\
\hline Euclea divinorum & Uswet (Tugen) & Ebenaceae & Shrub & $\begin{array}{l}\text { Firewood. Charcoal. Timber. Furniture. Poles. Tool handles. } \\
\text { Its roots are used as an emetic and purgative. Ornamental. Bee } \\
\text { forage. Walking sticks. Toothbrushes. Shade. Dye. }\end{array}$ \\
\hline Cordia sinensis & $\begin{array}{l}\text { Edome (Turkana) } \\
\text { Edoma (Tugen) }\end{array}$ & Boraginaceae & Shrub & $\begin{array}{l}\text { Used for firewood. Used for furniture. Leaves used as fodder. } \\
\text { Roots and bark used as medicine. Fruit used as glue. Utensils. } \\
\text { Edible fruit. }\end{array}$ \\
\hline Acacia tortilis & $\begin{array}{l}\text { Ewoi (Turkana) } \\
\text { Sesiet (Tugen) }\end{array}$ & $\begin{array}{c}\text { Fabaceae } \\
\text { (Mimosaceae) }\end{array}$ & Tree & $\begin{array}{l}\text { Used for firewood. Charcoal. Timber. Bee forage. Timber. } \\
\text { Edible pods. Medicine. Shade (meeting place for Turkana). } \\
\text { Ornamental. Live fence. Thorn used as pins. }\end{array}$ \\
\hline
\end{tabular}

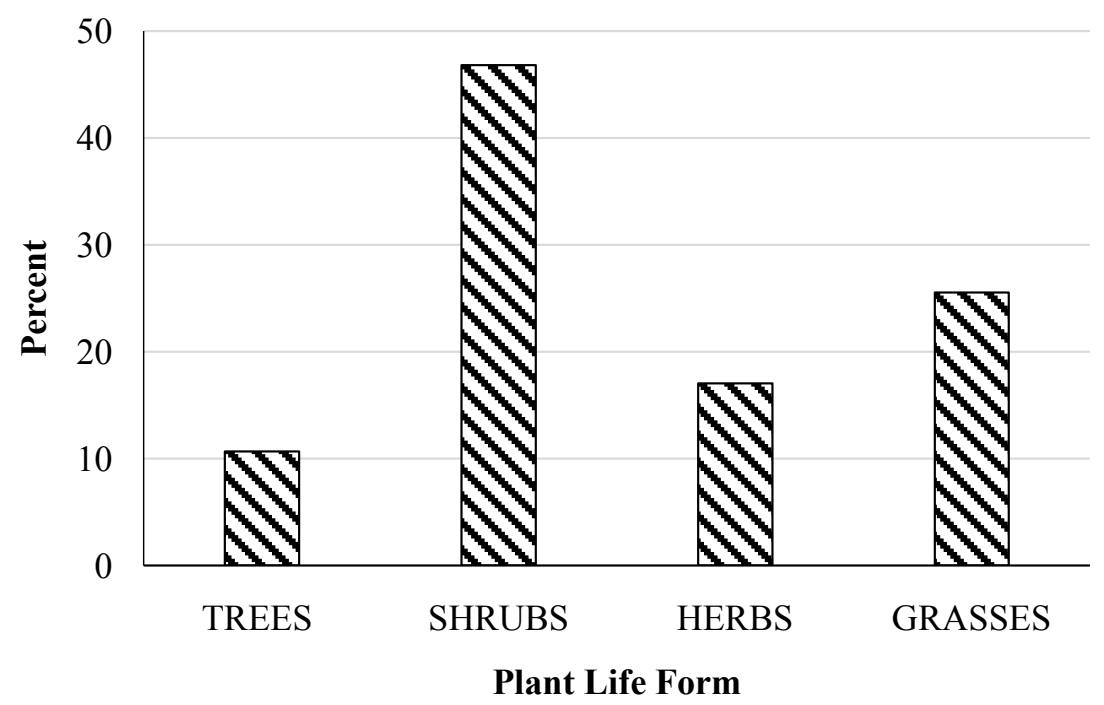

Figure 4. Proportions of the various life forms of plants at the Chemeron, South Baringo.

on the surface. Lastly, these plants may also be functioning together (commensalism) to ensure that both can survive in any given weather conditions. Invasive 


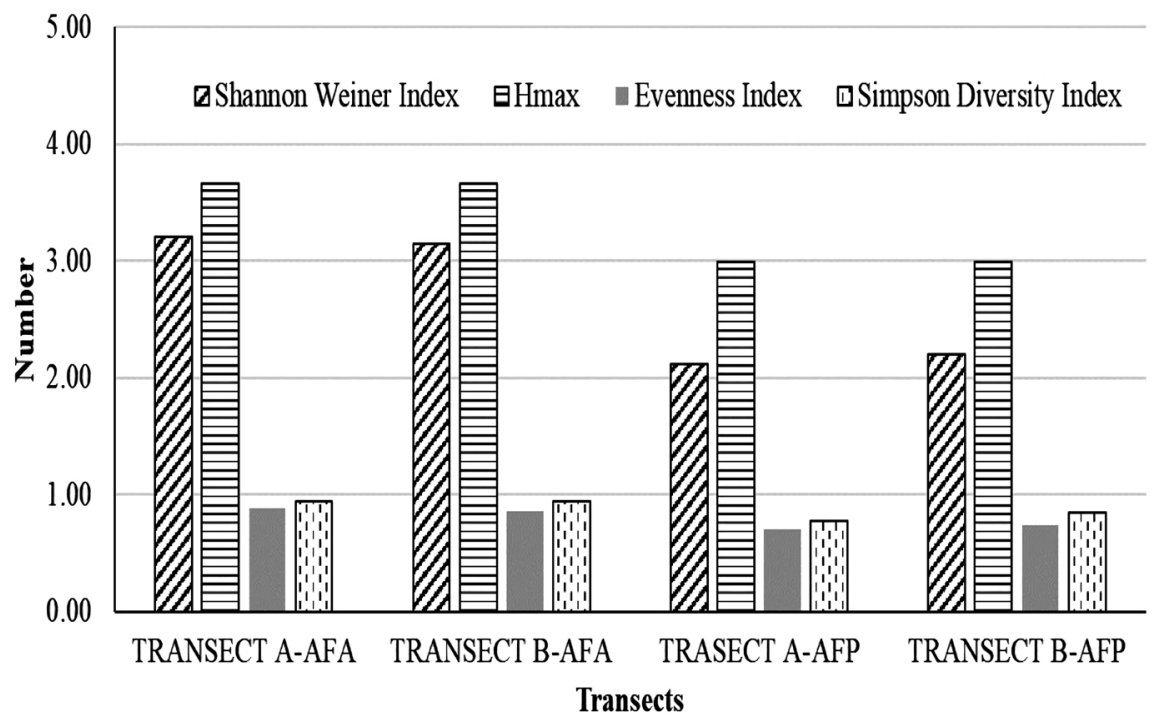

Figure 5. Various plant diversity indices at Chemeron DRTEC in Baringo county. Transect A-AFA: First Transect without Acalypha fruticosa; Transect B-AFA: Second Transect without Acalypha fruticosa; Transect B-AFP: First Trasect with Acalypha fruticosa present; Transect B-AFP: Second Trasect with Acalypha fruticosa presents.

plant species in Sub-Saharan Africa represent a potential agent of environmental degradation [15] through loss of biodiversity that is a major threat to the conservation and sustainable use of drylands [16]. Our findings are consistent with those of [17] that showed that invasive species can lead to a reduction in resource availability and/or suppress or enhance the relative abundance of the native plant species. Mangold et al. [3] observed that invasive plants are a threat to the integrity of rangelands and that they may alter the structure, organization, and function of rangeland plant communities. As noted in this study of the impact of Acalypha fruticosa, invasive species are considered a major threat to biological diversity and likely to displace native plants [3].

Species evenness refers to how close in numbers each species in an environment is. The higher the value, the more the richness. From the results obtained in the two sites, the $A$. fruticosa-absent site is richer in species than those where it is present. To measure species richness, we used the Simpson's diversity index. The bigger the Simpson's index value, the lower the diversity. Thus species richness was higher in areas where Acalypha fruticosa has been removed, suggesting the negative effects that the shrub has on other plant species in the rangeland. Enclosures and removal of invasive species have been used effectively within the rangelands as a resilience mechanism against drought to secure livelihoods in the ASALs of Kenya [15]. Further, they have been used to protect selected areas from overgrazing and enhance forage availability and curb degradation of these fragile ecosystems. Our findings are consistent with those of $\mathrm{Wu}$ et al. [18] that indicate that enclosures have a considerable positive influence on community structure and productivity, and thus strongly recommended as a management tool for rangelands conservation. Enclosures have also been shown to preserve 
some of the most important life forms (e.g. grasses and herbs) in rangelands that constitute livestock fodder leading to an increase in vegetation density, reduction in soil erosion, and increased forage availability [15].

Our study demonstrated a positive effect of the mechanical removal of Acalypha fruticosa on plant species diversity and abundance. These results are consistent with those of Ibrahim [1] that demonstrated the positive impact of enclosures on plant species composition in the rangelands of Ethiopia. Further, Crawley \& Del-Val [19] noted an increase in desirable or palatable grass species in enclosures compared to open grazing fields. Similar observations have been reported by Ibrahim [1] who further argues that enclosures are effective in restoring plant species composition, biomass and cover of herbaceous species. In the current study, the number of palatable grass species in the sites where Acalypha fruticosa had been removed was considerably higher than those with the invasive plant present. This observation is similar to that made by Ibrahim [1] that linked diminished plant species composition in open grazing fields to communal grazing and other inappropriate and unsustainable range utilization practices.

Acalypha fruticosa had minimal effects on Silene spp and Indigofera arrecta whose abundance in both sites (with and without $A$. fruticosa) was similar. The two species contributed greatly to the relative of figures observed in both sites. Decrease in species evenness and diversity is mostly driven by the cover and height of the copper leaf. The impact of the invasive species is normally associated with the degree of its dominance [20] [21] [22]. In our study, the more copper leaf present in a particular area, the lower the number of native species and thus reduced species diversity.

\section{Conclusion and Recommendation}

From our findings, the negative effects of Acalypha fruticosa (copper leaf) on native plant species diversity, relative abundance and community structure were evident. The invasive plant led to a reduction in plant species abundance, diversity and distribution thus reduced forage quantity and quality. The grasses and herbs were the most affected plants by $A$. fruticosa. This will indirectly lead to reduced carrying capacity of these rangelands and consequently a reduction in livestock production as well as a reduction in ecosystem services and functions. To counter the effects of copper leaf and therefore enhance forage availability and food security, paddocking and mechanical removal of this invasive species is recommended among the agro-pastoralists of South-Baringo. Such enclosures should be established in consultation with the local communities that utilize these grazing lands. There is also need to study the post-invasion plant community that develops as a result of the natural restoration processes.

\section{Acknowledgements}

We express our sincere gratitude to the Dryland Research Training and Eco- 
tourism Centre (DRTEC) team for their support and assistance during field planning and data collection. We are grateful to Mr. Edmunds Ojwaka, Mr. Olekaikai and Mr. Richard Chebii for their assistance in plant species identification. Further, we acknowledge the technical support we received from Mr. Geoffrey Maina in drawing the study map. Finally, we recognize the objective criticism and valuable comments and feedback we received from various reviewers of this paper.

\section{Conflicts of Interest}

The authors declare no conflicts of interest regarding the publication of this paper.

\section{References}

[1] Ibrahim, M.A. (2016) Impact of Enclosure on Plant Species Composition and Biomass Production in Ewa Woreda of Afar Region State, Ethiopia. Journal of Biodiversity \& Endangered Species, 4, 157. https://doi.org/10.4172/2332-2543.1000157

[2] Rosenzweig, M.L. (2001) The Four Questions: What Does the Introduction of Exotic Species Do to Diversity? Evolutionary Ecology Research, 3, 361-367.

[3] Mangold, J., Sheley, R.L. and Svejcar, T.J. (2006) Toward Ecologically-Based Invasive Plant Management on Rangelands. Weed Science, 54, 597-605.

https://doi.org/10.1614/WS-05-049R3.1

[4] Gurevitch, J. and Padilla, D.K. (2004) Are Invasive Species a Major Cause of Extinctions? Trends in Ecology and Evolution Journal, 19, 470-474.

https://doi.org/10.1016/j.tree.2004.07.005

[5] Williamson, M. (1998) Measuring the Impact of Plant Invaders in Britain. In: Starfinger, U., Edwards, K., Kowarik, I. and Williamson, M., Eds., Plant Invasions. Ecological Mechanisms and Human Responses, Backhuys Publ., Leiden, 57-68.

[6] Byers, J.E., Reichard, S., Smith, C.S., Parker, I.M., Randall, J.M., Lonsdale, W.M., Atkinson, I.A.E., Seasted, T., Chornesky, E., Hayes, D. and Williamson, M. (2002) Directing Research to Reduce the Impacts of Nonindigenous Species. Conservation Biology, 16, 630-640. https://doi.org/10.1046/j.1523-1739.2002.01057.x

[7] Schwartz, M.V., Thorne, J.H. and Viers, J.H. (2006) Biotic Homogenization of the California Flora in Urban and Urbanizing Regions. Biological Conservation, 127, 282-291. https://doi.org/10.1016/j.biocon.2005.05.017

[8] Callaway, R.M. and Ridenour, W.M. (2004) Novel Weapons: Invasive Success and the Evolution of Increased Competitive Ability. Frontiers in Ecology and the Environment, 2, 436-443. https://doi.org/10.1890/1540-9295(2004)002[0436:NWISAT]2.0.CO;2

[9] Chapin, F.S., Zavaleta, E.S., Eviner, V.T., Naylor, R.L., Vitousek, P.M., Reynolds, H.L., Hooper, D.U., Lavorel, S., Sala, O.E., Hobbie, S.E., Mack, M.C. and Díaz, S. (2000) Consequences of Changing Biodiversity. Nature, 405, 234-242.

[10] Hooper, D.U., Hector, A., Chapin, F.S., Inchausti, P., Lavorel, S., Lawton, J.S., Lodge, D.M., Loreau, M., Naeem, S., Schmid, B., Setala, H., Symstad, A.J., Vandermeer, J. and Wardle, D.A. (2005) Effects of Biodiversity on Ecosystem Functioning: A Consensus of Current Knowledge. Ecological Monographs, 75, 3-35. https://doi.org/10.1890/04-0922

[11] Gordon, D.R. (1998) Effects of Invasive, Non-Indigenous Plant Species on Ecosys- 
tem Processes: Lessons from Florida. Ecological Applications, 8, 975-989. https://doi.org/10.1890/1051-0761(1998)008[0975:EOINIP]2.0.CO;2

[12] Manchester, S.J. and Bullock, J.M. (2000) The Impacts of Non-Native Species on UK Biodiversity and the Effectiveness of Control. Journal of Applied Ecology, 37, 845-864. https://doi.org/10.1046/j.1365-2664.2000.00538.x

[13] Magurran, A.E. (1988) Ecological Diversity and Its Measurement. Cambridge University Press, Cambridge. https://doi.org/10.1007/978-94-015-7358-0

[14] Shannon, C.F. and Weiner, W. (1948) The Mathematical Theory of Communication. University of Illinois Press, Urbana. In: Razida, A., Joshi, S.P. and Srivastava M.M. (1980) Composition and Diversity of Vegetation in Alpine Grasslands in Garhnal Himalaya. Tropical Ecology, 39, 139-141.

[15] Vajari, M., Maziar, S.R. and Jalali, A.M. (2012) A Survey on Effects of Enclosure on Vegetation Dynamic of Rangelands of Guilan Province. International Journal of Agriculture and Crop Sciences, 4, 92-97.

[16] Obiri, J.F. (2011) Invasive Plant Species and Their Disaster-Effects in Dry Tropical Forests and Rangelands of Kenya and Tanzania. Journal of Disaster Risk Studies, 3, 417-428. https://doi.org/10.4102/jamba.v3i2.39

[17] MacDougall, A. and Turkington, R. (2005) Are Invasive Species the Drivers or Passengers of Change in Degraded Ecosystems? Ecology, 86, 42-55. https://doi.org/10.1890/04-0669

[18] Wu, G., Du, G., Liu, Z. and Thirgood, S. (2009) Effect of Fencing and Grazing on a Kobresia-Dominated Meadow in the Qinghai-Tibetan, Plateau. Plant and Soil, 319, 115-126. https://doi.org/10.1007/s11104-008-9854-3

[19] Crawley, M.J. and Del-val, E. (2005) Are Grazing Increaser Species Better Tolerators than Decreasers? An Environmental Assessment of Defoliation Tolerance in Eight British Grassland Species. Journal of Ecology, 93, 1005-1016. https://doi.org/10.1111/j.1365-2745.2005.01011.x

[20] Richardson, D.M., Macdonald, I.A. and Forsyth, G.C. (1989) Reduction in Plant Species Richness under Stands of Alien Trees and Shrubs in Fynbos Biome. South African Forestry Journal, 149, 1-8. https://doi.org/10.1080/00382167.1989.9628986

[21] Pysek, P. and Pysek, A. (1995) Invasion by Heracleum Mantegazzianum in Different Habitats in the Czech Republic. Journal of Vegetation Science, 6, 711-718. https://doi.org/10.2307/3236442

[22] Hejda, M., Pysek, P. and Jarosík, V. (2009) Impact of Invasive Plants on the Species Richness, Diversity and Composition of Invaded Communities. Journal of Ecology, 97, 393-403. https://doi.org/10.1111/j.1365-2745.2009.01480.x 